SJ Quinney College of Law, University of Utah Utah Law Digital Commons

2015

\title{
Blinding Prosecutors to Defendants' Race: A Policy Proposal to Reduce Unconscious Bias in the Criminal Justice System
}

Shima Baughman

S.J. Quinney College of Law, University of Utah, shima.baughman@law.utah.edu

Sunita Sah

Christopher T. Robertson

Follow this and additional works at: http://dc.law.utah.edu/scholarship

Part of the Criminal Law Commons, Criminal Procedure Commons, and the Law and Race Commons

\section{Recommended Citation}

Sah, S., Robertson, C. T., \& Baughman, S. B. (2015). Blinding prosecutors to defendants' race: A policy proposal to reduce unconscious bias in the criminal justice system. Behavioral Science \& Policy, 1(2), pp. 69-76

This Article is brought to you for free and open access by the Utah Law Scholarship at Utah Law Digital Commons. It has been accepted for inclusion in Utah Law Faculty Scholarship by an authorized administrator of Utah Law Digital Commons. For more information, please contact 


\section{blinding prosecutors}

to defendants' race: a
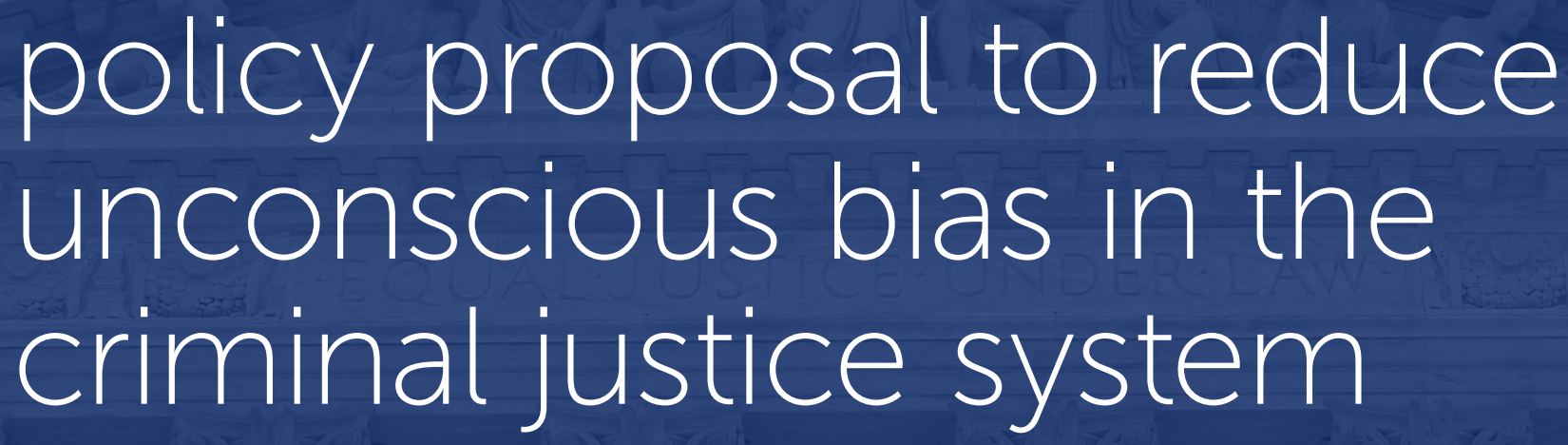

Sunita Sah, Christopher T. Robertson, \& Shima B. Baughman

\section{abstract}

Racial minorities are disproportionately imprisoned in the United States. This disparity is unlikely to be due solely to differences in criminal behavior. Behavioral science research has documented that prosecutors harbor unconscious racial biases. These unconscious biases play a role whenever prosecutors exercise their broad discretion, such as in choosing what crimes to charge and when negotiating plea bargains. To reduce this risk of unconscious racial bias, we propose a policy change: Prosecutors should be blinded to the race of criminal defendants wherever feasible. This could be accomplished by removing information identifying or suggesting the defendant's race from police dossiers shared with prosecutors and by avoiding mentions of race in conversations between prosecutors and defense attorneys. Race is almost always irrelevant to the merits of a criminal prosecution; it should be omitted from the proceedings whenever possible for the sake of justice. 


\title{
proposal
}

\section{Blinding prosecutors to defendants' race: A policy proposal to reduce unconscious bias in the criminal justice system}

\author{
Sunita Sah, Christopher T. Robertson, \& Shima B. Baughman
}

absract. Racial minorities are disproportionately imprisoned in the United States. This disparity is unlikely to be due solely to differences in criminal behavior. Behavioral science research has documented that prosecutors harbor unconscious racial biases. These unconscious biases play a role whenever prosecutors exercise their broad discretion, such as in choosing what crimes to charge and when negotiating plea bargains. To reduce this risk of unconscious racial bias, we propose a policy change: Prosecutors should be blinded to the race of criminal defendants wherever feasible. This could be accomplished by removing information identifying or suggesting the defendant's race from police dossiers shared with prosecutors and by avoiding mentions of race in conversations between prosecutors and defense attorneys. Race is almost always irrelevant to the merits of a criminal prosecution; it should be omitted from the proceedings whenever possible for the sake of justice.

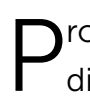
rosecutors may have more independent power and discretion than any other government officials in the United States. ${ }^{1}$ Prosecutors decide whether to initiate criminal proceedings, what charges to file or bring before a grand jury, how and when to prosecute individuals, and what penalties to seek. For a given criminal behavior, half a dozen charges might apply, ranging from minor misdemeanors to the most serious felonies. A prosecutor can decline to press charges altogether or stack charges by characterizing the same behavior as

Sah, S., Robertson, C. T., \& Baughman, S. B. (2015). Blinding prosecutors to defendants' race: A policy proposal to reduce unconscious bias in the criminal justice system. Behavioral Science \& Policy, 1(2), pp. 69-76. violating the law dozens of times (charging each phone call made as part of a drug transaction as a crime, for instance). Once charged, about $95 \%$ of criminal cases are resolved through plea bargaining, where prosecutors can defer prosecution, suspend a sentence, minimize factual allegations in ways that virtually guarantee a light sentence, or insist on the most severe penalties. ${ }^{2}$ If a case does go to trial, a prosecutor's sentencing demand provides an influential reference point (an anchor) for a defense attorney's response in plea negotiations and the judge's final sentencing decision. ${ }^{3}$

Prosecutors typically do not need to articulate the bases for their discretionary decisions, ${ }^{4,5}$ and these decisions receive only minimal scrutiny from the courts. 
Although the U.S. Constitution theoretically limits the discretion of prosecutors (to target a particular race prejudicially, for instance), such protections are exceedingly difficult to invoke, ${ }^{6}$ especially if a prosecutor's unconscious rather than intentional bias is in play. ${ }^{7}$ This context prompts us to offer an important and novel proposal with the potential to help make the justice system blind to race.

Prosecutors, we believe, should be unaware of defendants' race whenever possible. Implementing such a significant change would be challenging, clearly. But evidence of persistent disparities regarding the proportion of racial minorities that are put in prison makes the need for change apparent. And growing evidence that prosecutors' unconscious biases contribute to that imbalance gives us a potentially powerful target for efforts to produce positive and vitally needed change.

\section{Racial Bias in the Criminal Justice System}

In 2010 in the United States, Blacks made up 38\% of all prisoners, although they made up only $12 \%$ of the national population. ${ }^{8}$ That same year, about one in 23 Black men was in prison, compared with one in 147 White men. ${ }^{9}$ The causes of this racial disparity are many and complex. Socioeconomic factors (poverty and lower educational achievement, for example) play a role. So may inequitable police behavior that, for example, leads to Blacks being stopped and frisked more often than Whites are. ${ }^{10,11}$

Black defendants also tend to receive harsher sentences than White defendants do, even when both the severity of the crime and previous criminal history are taken into account. ${ }^{12}$ For example, harsher punishment was applied to crimes related to crack cocaine versus powder cocaine in federal sentencing guidelines, which tended to punish Blacks more harshly because they were more likely to be arrested with crack cocaine than powder cocaine. To minimize this disparate impact on Blacks, Congress passed the Fair Sentencing Act in 2010, which reduced the unequal penalties and eliminated the five-year mandatory minimum sentence for simple crack cocaine possession. This new law addressed the racial bias perpetrated by the old regime that led to low-level crack dealers, who were often Black, receiving more severe sentences than wholesale suppliers of powdered cocaine. ${ }^{13}$
One important cause of the racial discrepancy among prisoners, however, is bias that affects discretionary decisions made by prosecutors. ${ }^{14-17}$ A recent review of empirical studies examining prosecutorial decision making and race found that most of the studies suggested that the defendants' "race directly or indirectly influenced case outcomes, even when a host of other legal or extra-legal factors are taken into account."17 Minorities, particularly Black males, "receive disproportionately harsher treatment at each stage of the prosecutorial decision-making process." ${ }^{18}$ Indeed, prosecutors in predominantly Black communities have been shown to make racially biased decisions, such as overcharging Black youth, ${ }^{19}$ which, in turn, perpetuates racial stereotypes. ${ }^{20,21}$ Further, Black children in the United States are much more likely than White children to be sentenced as adults, ${ }^{22}$ probably because Black juveniles are perceived to be older and less childlike than White juveniles. ${ }^{23,24}$

These data do not suggest that prosecutors are overtly racist, although some may be. Instead, research documents that bias can infect even people with the best of intentions, including physicians and other professionals. ${ }^{25,26}$ Prosecutors are humans with bounded rationality, making decisions in a cultural milieu that shapes their perceptions and decisions on an unconscious level. ${ }^{15,27,28}$ Generally, bias increases in ambiguous situations, ${ }^{20,29-33}$ and as we described previously, decisions on what and how many charges to file against a defendant are inherently ambiguous.

Behavioral science researchers have demonstrated that people unknowingly misremember case facts in racially biased ways. ${ }^{34,35}$ For example, there is a greater tendency to remember aggressive actions (e.g., punches or kicks) if a suspect is Black. ${ }^{34}$ In fact, it appears that the more stereotypically Black a defendant is perceived to be, the more likely that person is to be sentenced to death. ${ }^{36}$ In one study, Stanford University students viewed photographs of Black men, rating each one on the degree to which the person's appearance was stereotypically Black. The students were told they could base their decisions on any of the features of the photographed subjects to make their decisions, including noses, lips, skin tone, and hair. Unbeknownst to the students, each man in the images had been convicted of murdering a White person. The men the students rated as appearing more stereotypically Black were more likely to have been sentenced to death in criminal 
proceedings. ${ }^{36}$ Other research has demonstrated that lighter skin tones may lead to more lenient judgments and prison sentences. ${ }^{20,37}$

Although bias exists throughout the criminal justice system, bias in prosecutorial decisions has a potentially disproportionate impact, given that most criminal cases do not go to trial and prosecutors exercise such wide discretion in handling them. One might hope that selecting prosecutors of good faith and asking them to behave professionally could avert racial bias. In this vein, in 2014, the Department of Justice reaffirmed its policy that "in making decisions ... law enforcement officers may not use race."38 Such a policy, although laudable, unfortunately cannot prevent unconscious bias.

Prosecutorial decisions are made in a more deliberative fashion than, for example, split-second decisions made by police to shoot or not shoot. However, even with deliberative decisions, the ability to self-regulate bias is difficult: Moral reasoning is usually a post hoc construction, generated after a (usually intuitive) judgment has been reached, ${ }^{39}$ often influenced by erroneous factors. ${ }^{40}$ People exhibiting bias are typically unaware that they are doing so, and bias is often unintentional. ${ }^{33,41,42}$ Educating people on unconscious bias often leads them to be convinced that other people are biased but that they themselves are not. ${ }^{29}$ Accordingly, strategies to encourage people to become less biased are usually not sufficient.

One program that had some success in reducing racial disparities was the 2006 Prosecution and Racial Justice Program of the Vera Institute of Justice. Prosecutors collected and published data on defendant and victim race for each offense category and the prosecutorial action taken at each stage of criminal proceedings. ${ }^{43}$ These data exposed that similarly situated defendants of different races were treated differently at each stage of discretion: initial case screening, charging, plea offers, and final disposition. For instance, in Wisconsin, the data showed that prosecutors were charging Black defendants at higher rates than White defendants for drug possession. With this information, the district attorney made an office policy to refer suspects to drug treatment rather than charging them in an attempt to reduce racial bias in charging. However, this approach requires a large investment from overburdened prosecutorial offices to collect and analyze their data to reveal trends in racial disparity. It also requires that individual prosecutors be motivated to consciously avoid bias or at least be motivated to appear unbiased. ${ }^{44,45}$ This motivation is often led by societal norms or public pressure regarding racial attitudes and inequality, which varies by jurisdiction. There presently is no complete solution to eliminate racial bias in prosecutorial decisions.

\section{Blinding: An Alternative Approach to Managing Bias}

An alternative way to manage bias is to acknowledge its existence and create institutional procedures to prevent bias from influencing important decisions. The psychologist Robert Rosenthal, a leading methodologist, concluded that the best way to reduce the chances of bias unconsciously affecting decision processes is to keep the process "as blind as possible for as long as possible." ${ }^{n 6}$

Blinding (or masking) to improve decisionmaking has a long history in different domains. For example, having musicians audition behind a screen decreased gender bias and increased the acceptance rate of women into symphony orchestras. ${ }^{47}$ In medical science, both subjects and researchers are, whenever feasible, kept unaware of who is in the treatment or control groups of clinical trials, in an effort to achieve unbiased results. ${ }^{48}$ Meta-analyses have shown that such blinding reduces the number of false positives in science experiments. ${ }^{49,50}$ Similarly, editors of scholarly journals routinely remove authors' names and institutions from submissions so they can assess articles on their scientific merits alone. ${ }^{51}$ Likewise, to avoid possible favoritism, some professors mask students' identities on papers when grading. ${ }^{52}$

Blinding is already in use in other stages of the criminal justice process. For example, lineups are widely acknowledged to be best conducted by an officer who does not know which person is the suspect, so as not to pollute the eyewitness's perceptions. ${ }^{53,54}$ This practice of blind administration of lineups was originally highly controversial. lowa State University professor Gary Wells first proposed implementing blinding of police to suspect lineups in $1988,{ }^{55}$ although evidence of bias and erroneous identification had been accumulating for years before that. More than a decade later, in 1999, the U.S. Department of Justice published a set of best practices for conducting police lineups ${ }^{56}$ that excluded blind procedures (although it acknowledged that having investigators who did not know which person in the 
lineup was the suspect was desirable) because blinding "may be impractical for some jurisdictions to implement" (p. 9). ${ }^{56}$ Nevertheless, individual jurisdictions experimented with blind procedures. ${ }^{57}$ By 2014, the National Research Council recommended unreservedly that all lineups should be conducted with the benefits of blinding. 58

Blinding has also been recommended for forensic scientists and other expert witnesses, so that attorneys for either side in a case do not influence and undermine their scientific expertise. ${ }^{32}$ More generally, the rules of evidence (which determine what is permissible in court) can be understood as an elaborate blinding procedure, designed to ensure that juries are not exposed to irrelevant or unreliable evidence, recognizing that for the purpose of assessing guilt, some factors are more prejudicial than probative. ${ }^{59}$

\section{The Case for Blinded Prosecutors}

The success of the long-standing practice of blinding in other contexts gives credence to our proposal that prosecutors should be blinded to the race of criminal defendants whenever possible. Prosecutors, like other professionals, cannot be biased by what they do not know. In addition to mitigating unconscious bias, the blinding of prosecutors also mitigates any conscious racism, which may infect some prosecutors.

Federal prosecutors already use a race-blinding procedure for death penalty decisions. The Department of Justice requires that attorneys on committees of capital cases (which determine death eligibility) review each defendant file only after information related to the race of the defendant has been removed. ${ }^{60}$ Only paralegal assistants who collect statistics know the defendants' races. The question is how far this practice can and should be expanded. We believe there is potential for broader use of race blinding by other prosecutors. Prosecutors are a good target for race blinding given their substantial power and impact, particularly with two pivotal decisions: the filing of charges and the negotiation of plea bargains.

\section{Charging Decisions}

Prosecutorial practice varies in different jurisdictions. For petty offenses, a prosecutor may make key decisions in court while facing defendants, making blinding infeasible (unless that dynamic itself is reformed). In many jurisdictions, however, prosecutors do not see defendants in person when making initial charging decisions; these are based on information provided in police dossiers, in which race could be redacted. In fact, the trend is for such information to be conveyed to prosecutors electronically, making it easier to filter the race information, perhaps automatically by electronic tools or by intermediaries. In either case, race information could be retained for other uses such as identification or demographic tracking. As the Department of Justice capital-case review committees show, some assistants can have access to a full criminal file while decisionmakers see only race-blind information.

\section{Plea Bargaining}

Although defendants retain the ultimate choice about whether to accept any deal, the prosecuting and defense attorneys actually negotiate that deal, and the prosecutor need not be exposed to the race of the defendant. In some jurisdictions, plea bargaining happens at arraignments with defendants in the same room. But this practice is neither uniform nor necessary. Thus, the two steps that are conclusive for the vast majority of cases-charging decisions and plea bargaining-can potentially be blinded to race.

\section{Limitations, Challenges, and the Need for Pilot Testing}

Although we argue for the value of race blinding procedures, we acknowledge that there will be difficulties and limitations in implementing such a policy. Race should have no legitimate role in the vast majority of charging decisions. However, in rare situations, such as prosecutions for hate crime, the race of an alleged perpetrator is relevant. In these cases, the necessary information can be provided to prosecutors.

For cases in which race is irrelevant, the blinding strategy will be effective at eliminating bias only to the extent that prosecutors are unable to infer race from other information available to them. Thus, it will be necessary to remove information that could reveal race, such as photos of a defendant; the defendant's name; and, in racially segregated communities, the defendant's 
address. The practicalities of removing all race-related information could become complex. Further, race blinding may not be feasible if photos contain relevant information (such as defensive wounds on the defendant's skin) or eyewitness testimony describes a perpetrator's race.

To prevent prosecutors from inferring race from the defendants' names, court documents could instead identify defendants with assigned numbers (such as driver's license numbers). That said, removing names may have other unintended effects, such as reducing empathy, leading to harsher decisions toward anonymous defendants. ${ }^{62}$ An alternative approach would be the use of random race-neutral pseudonyms to achieve anonymity without erasing all trace that a person is involved.

The severity of punishment is a question for the legislature. If race blinding succeeds, it levels the playing field for all by promoting equality, even if it decreases bias favorable to White defendants (often referred to as White privilege). ${ }^{63-65}$ Both unjustified leniency for Whites and unjustified harsher punishments for Blacks were revealed in 2015 by the U.S. Department of Justice Civil Rights Division's investigation of the Ferguson (Missouri) Police Department. Of the many examples discussed in the report, one clearly highlighted the double standards: Whites were more likely to have citations, fines, and fees eliminated by city officials, whereas Blacks were punished for the same minor transgressions with expensive tickets and judgments punishing their perceived lack of personal responsibility (pp. 74-75). ${ }^{66}$ That said, in other contexts, punishments may be harsher for Whites than for Blacks. ${ }^{17}$ Blinding may create racial equity for both Black and White defendants.

Given that race blinding may not be feasible in some situations, may fail, or may have unintended consequences, the best path forward is to pilot-test this intervention and gauge its effectiveness. Pilot testing would allow researchers to uncover (and perhaps creatively address) challenges in the practical implementation of race blinding; evaluate on a smaller scale the precise impact, success, and value of race blinding; and expose any potential unintended consequences. ${ }^{33,67-69}$ Sequential rollouts in different jurisdictions are also valuable, as they allow for continued monitoring and assessment in varying contexts.

In theory, prosecutors could be blinded to other information that may activate biases, including the race of the victim or the gender of the defendant or victim. These reforms should be considered on their own merits, including whether empirical evidence demonstrates that these variables are biasing prosecutorial decisions in a systematic fashion that is irrelevant to the proper application of the law. These considerations would also apply to whether blinding could be expanded to other decision-makers, including defense attorneys, judges, juries, and parole boards.

\section{Impact and Cost Effectiveness}

The need to eliminate race bias in prosecution is urgent. Racial biases can substantially distort decisions, ${ }^{61,70}$ and prosecutorial bias alone leads to a substantial increase in the duration and severity of punishment for minorities. A study using 222,542 cases in New York County during 2010-2011 found that Black defendants were $10 \%$ more likely to be detained pretrial compared with White defendants charged with similar crimes, and they were $13 \%$ more likely to receive offers of prison sentences during plea bargaining. ${ }^{71}$ Given that a prosecutor typically handles dozens of felonies and over a hundred misdemeanors per year, ${ }^{72}$ the impact of racial bias is compounded. Approximately 27,000 state prosecutors deal with 2.9 million felony cases per year, and 6,075 federal prosecutors secure 82,000 convictions per year, not to mention the millions of prosecutorial decisions that are made on misdemeanor charges. ${ }^{73,74}$ Two-thirds of those convicted of a felony go to prison, and the average sentence is about five years, ${ }^{75}$ at a cost of $\$ 25,000$ per prisoner per year. ${ }^{76}$ Therefore, given that prosecutors are responsible for hundreds of personyears of incarceration annually and thus millions of dollars of public money, even a marginal reduction in bias may have a substantial effect.

These numbers have an impact that extends beyond the direct experiences of people sentenced to do time. As The Pew Charitable Trusts reported in 2010, the income of households and the educational success of children in those households decline when parents are put in jail. ${ }^{77}$ The tangible and intangible costs to the prisoners, their families, and the broader society are tremendous.

Successfully blinding prosecutors to defendants' race may also improve the perceived legitimacy of prosecutorial decisions, which may enhance 
compliance with the law. ${ }^{78}$ As important as anything else, it would advance some of the fundamental goals of our government: the equal treatment of all citizens and justice for all.

\section{A New Standard: Blinding Prosecutors to Defendants' Race}

If race blinding proves to be effective after pilot testing, we recommend that local and state prosecutors and the federal Department of Justice adopt race blinding as a uniform practice. We recommend that national and statewide associations of prosecutors (for example, the National District Attorneys Association), as well as broader organizations such as the American Bar Association (ABA), support implementation of the reforms. Furthermore, we recommend that this imperative be written into ethical codes and guidelines, such as the U.S. Attorneys' Handbook Chapter 9-27.000 (USAM) and Rule 3.8 of the ABA Model Rules of Professional Conduct (1983). Our reform also relies on the ethical behavior of attorneys, police, and other intermediaries who would not leak the race of the defendant to prosecutors. Adoption of this norm into the current ethical code could build on the current norms of confidentiality.

Race disparities pervade criminal justice decisionmaking in America. Among criminal-justice actors, the decisions of prosecutors are the least reviewable, are exercised with the most discretion, and are impactful. Blinding has been used as a tool to reduce gender and race discrimination in many fields, and its value is grounded in empirical evidence. We believe that blinding prosecutors to a defendant's race wherever feasible is a timely and important proposal.

We acknowledge that there will be practical implementation challenges and risks. Our primary aim with this proposal is to instigate a discussion on the merits and drawbacks of blinding prosecutors to race and to encourage pilot tests. The Department of Justice demonstrated the feasibility of race blinding for federal prosecutors ${ }^{60}$ and state prosecutors could follow suit with similar procedures for their own death penalty cases. Expanding race blinding to other prosecutorial decisions may seem impractical; but, if the history of blind police lineups is any guide, ${ }^{55}$ the jurisdictions most committed to racial equality and behaviorally informed policymaking will prove otherwise.

\section{author affiliation}

Sah, Johnson Graduate School of Management, Cornell University; Robertson, College of Law, University of Arizona; Baughman, College of Law, University of Utah. Corresponding author's e-mail: sunita.sah acornell.edu

\section{References}

1. Bibas, S. (2009). Prosecutorial regulation versus prosecutorial accountability. University of Pennsylvania Law Review, 157, 959-1016.

2. Bibas, S. (2006). Transparency and participation in criminal procedure. New York University Law Review, 86, 911-912.

3. Englich, B. (2006). Blind or biased? Justitia's susceptibility to anchoring effects in the courtroom based on given numerical representations. Law \& Policy, 28, 497-514.

4. Rabin, R. L. (1972). Agency criminal referrals in the federal system: An empirical study of prosecutorial discretion. Stanford Law Review, 24, 1036-1091.

5. Leonetti, C. (2012). When the emperor has no clothes III: Personnel policies and conflicts of interest in prosecutors' offices. Cornell Journal of Law and Public Policy, 22, 53-92.

6. Wayte v. United States, 470 U.S. 598 (1985).

7. McCleskey v. Kemp, 481 U.S. 279 (1987).

8. Guerino, P., Harrison, P. M., \& Sabol, W. J. (2011). Prisoners in 2010 (NCJ 236096). Retrieved from Bureau of Justice Statistics website: http://www.bjs.gov/content/pub/pdf/p10.pdf

9. Glaze, L. E. (2011). Correctional populations in the United States, 2010 (NCJ 236319). Retrieved from Bureau of Justice Statistics website: http://bjs.ojp.usdoj.gov/content/pub/pdf/ cpus10.pdf

10. Fagan, J., \& Meares, T. L. (2008). Punishment, deterrence and social control: The paradox of punishment in minority communities. Ohio State Journal of Criminal Law, 6, 173-229.

11. Sommers, S. R., \& Marotta, S. A. (2014). Racial disparities in legal outcomes on policing, charging decisions, and criminal trial proceedings. Policy Insights from the Behavioral and Brain Sciences, 1, 103-111.

12. Mitchell, O. (2005). A meta-analysis of race and sentencing research: Explaining the inconsistencies. Journal of Quantatative Criminolgy, 21, 439-466.

13. Fair Sentencing Act of 2010, Pub. L. No. 111-120, 21 U.S.C. g 1789, 124 Stat. 2372 (2010).

14. Tonry, M. (2011). Punishing race: A continuing American dilemma. New York, NY: Oxford University Press.

15. Burke, A. S. (2006). Improving prosecutorial decision making: Some lessons of cognitive science. William \& Mary Law Review, $47,1587-1633$.

16. Smith, A. (2001). Can you be a good person and a good prosecutor? Georgetown Journal of Legal Ethics, 14, 355-400.

17. Kutateladze, B., Lynn, V., \& Liang, E. (2012). Do race and ethnicity matter in prosecution? A review of empirical studies. Retrieved from Vera Institute of Justice website: http://www. vera.org/sites/default/files/resources/downloads/race-andethnicity-in-prosecution-first-edition.pdf

18. Johnson, J. L. (2014). Mass incarceration on trial: A remarkable court decision and the future of prisons in America. New York, NY: New Press.

19. Henning, K. N. (2013). Criminalizing normal adolescent behavior in communities of color: The role of prosecutors in juvenile justice reform. Cornell Law Review, 98, 383-462. 
20. Levinson, J. D., \& Young, D. (2010). Different shades of bias: Skin tone, implicit racial bias, and judgments of ambiguous evidence. West Virginia Law Review, 112, 307-350.

21. Correll, J., Park, B., Judd, C. M., \& Wittenbrink, B. (2007). The influence of stereotypes on decisions to shoot. European Journal of Social Psychology, 37, 1102-1117.

22. Hartney, C., \& Silva, F. (2007). And justice for some: Differential treatment of youth of color in the justice system. Retrieved from National Council on Crime and Delinquency website: http://www.nccdglobal.org/sites/default/files/publication_pdf/ justice-for-some.pdf

23. Rattan, A., Levine, C. S., Dweck, C. S., Eberhardt, J. L., $\&$ Avenanti, A. (2012). Race and the fragility of the legal distinction between juveniles and adults. PLOS ONE, 7(5), Article e36680.

24. Goff, P. A., Jackson, M. C., Di Leone, B. A. L., Culotta, C. M., \& DiTomasso, N. A. (2014). The essence of innocence: Consequences of dehumanizing Black children. Journal of Personality and Social Psychology, 106, 526-545.

25. Sah, S., \& Fugh-Berman, A. (2013). Physicians under the influence: Social psychology and industry marketing strategies. Journal of Law, Medicine and Ethics, 41, 665-672.

26. Sah, S. (2013). Essays on conflicts of interest in medicine. Business \& Society, 52, 666-678.

27. Johnson, S. L. (1988). Unconscious racism and the criminal law. Cornell Law Review, 73, 1016-1037.

28. Lawrence, C. R. (1987). The id, the ego, and equal protection: Reckoning with unconscious racism. Stanford Law Review, 38, 317-388.

29. Babcock, L., \& Loewenstein, G. (1997). Explaining bargaining impasse: The role of self-serving biases. The Journal of Economic Perspectives, 11, 109-126.

30. Sah, S., \& Larrick, R. (2015). I am immune: A sense of invulnerability predicts increased acceptance of, and influence from, conflicts of interest (Cornell University Working Papers).

31. Sah, S., \& Loewenstein, G. (2010). Effect of reminders of personal sacrifice and suggested rationalizations on residents self-reported willingness to accept gifts: A randomized trial. Journal of the American Medical Association, 304, 1204-1211.

32. Dror, I. E., \& Cole, S. A. (2010). The vision in "blind" justice: Expert perception, judgment, and visual cognition in forensic pattern recognition. Psychonomic Bulletin \& Review, 17, 161-167.

33. Sah, S. (2012). Conflicts of interest and your physician: Psychological processes that cause unexpected changes in behavior. Journal of Law, Medicine \& Ethics, 40, 482-487.

34. Levinson, J. D. (2007). Forgotten racial equality: Implicit bias, decisionmaking, and misremembering. Duke Law Journal, 57 , 345-424

35. Oliver, M. B. (1999). Caucasian viewers' memory of Black and White criminal suspects in the news. Journal of Communication, 49, 46-60.

36. Eberhardt, J. L., Davies, P. G., Purdie-Vaughns, V. J., \& Johnson, S. L. (2006). Looking deathworthy: Perceived stereotypicality of Black defendants predicts capitalsentencing outcomes. Psychological Science, 17, 383-386.

37. Viglione, J., Hannon, L., \& DeFina, R. (2011). The impact of light skin on prison time for Black female offenders. The Social Science Journal, 48, 250-258.

38. U.S. Department of Justice. (2014). Guidance for Federal law enforcement agencies regarding the use of race, ethnicity, gender, national origin, religion, sexual orientation, or gender identity. Retrieved from http://www.justice.gov/sites/default/ files/ag/pages/attachments/2014/12/08/use-of-race-policy.pdf

39. Haidt, J. (2001). The emotional dog and its rational tail: $A$ social intuitionist approach to moral judgment. Psychological Review, 108, 814-834.
40. Gunia, B. C., Barnes, C. M., \& Sah, S. (2014). The morality of larks and owls: Unethical behavior depends on chronotype as well as time of day. Psychological Science, 25, 2271-2274.

41. Pronin, E., Lin, D. Y., \& Ross, L. (2002). The bias blind spot: Perceptions of bias in self versus others. Personality and Social Psychology Bulletin, 28, 369-391.

42. Pronin, E., Gilovich, T., \& Ross, L. (2004). Objectivity in the eye of the beholder: Divergent perceptions of bias in self versus others. Psychological Review, 111, 781-799.

43. Davis, A. J. (2013). In search of racial justice: The role of the prosecutor. New York University Journal of Legislation and Public Policy, 16, 821-851.

44. Sah, S., \& Loewenstein, G. (2014). Nothing to declare: Mandatory and voluntary disclosure leads advisors to avoid conflicts of interest. Psychological Science, 25, 575-584.

45. Plant, E. A. (2004). Responses to interracial interactions over time. Personality and Social Psychology Bulletin, 30, $1458-1471$.

46. Rosenthal, R. (1978). How often are our numbers wrong? American Psychologist, 33, 1005-1008.

47. Goldin, C., \& Rouse, C. (2000). Orchestrating impartiality: The impact of "blind" auditions on female musicians. The American Economic Review, 90, 715-741.

48. Schulz, K. F., \& Grimes, D. A. (2002). Blinding in randomised trials: Hiding who got what. The Lancet, 359, 696-700.

49. Wood, L., Egger, M., Gluud, L. L., Schulz, K. F., Juni, P., Altman, D. G., ... Sterne, J. A. C. (2008). Empirical evidence of bias in treatment effect estimates in controlled trials with different interventions and outcomes: Meta-epidemiological study. British Medical Journal, 336, 601-605.

50. Psaty, B. M., \& Prentice, R. L. (2010). Minimizing bias in randomized trials: The importance of blinding. Journal of the American Medical Association, 304, 793-794.

51. Snodgrass, R. (2006). Single- versus double-blind reviewing: An analysis of the literature. ACM SIGMOD Record, 35(3), $8-21$.

52. Carrington, P. D. (1992). One law: The role of legal education in the opening of the legal profession since 1776. Florida Law Review, 44, 501-603.

53. Dysart, J. E., Lawson, V. Z., \& Rainey, A. (2012). Blind lineup administration as a prophylactic against the postidentification feedback effect. Law and Human Behavior, 36, 312-319.

54. Garrett, B. L. (2014). Eyewitness identifications and police practices: A Virginia case study. Virginia Journal of Criminal Law, 2, 2013-2026.

55. Wells, G. L. (1988). Eyewitness identification: A system handbook. Toronto, Ontario, Canada: Carswell Legal.

56. U.S. Department of Justice, Technical Working Group for Eyewitness Evidence. (1999). Eyewitness evidence: A guide for law enforcement (NCJ 178240). Retrieved from https://www. ncjrs.gov/pdffiles1/nij/178240.pdf

57. Famer, J. J. J. (2001, April 18). Attorney general guidelines for preparing and conducting photo and live lineup identification procedures [Letter]. Retrieved from State of New Jersey website: http://www.state.nj.us/lps/dcj/agguide/ photoid.pdf

58. National Research Council. (2014). Identifying the culprit: Assessing eyewitness identification. Washington, DC: National Academies Press.

59. Federal Rules of Evidence: Rule 403. Excluding relevant evidence for prejudice, confusion, waste of time, or other reasons. Retrieved from Legal Information Institute website: https://www.law.cornell.edu/rules/fre/rule_403

60. U.S. Department of Justice. (2001). The federal death penalty system: Supplementary data, analysis and revised protocol for capital case review. Retrieved from http://www.justice.gov/ archive/dag/pubdoc/deathpenaltystudy.htm 
61. Milkman, K. L., Akinola, M., \& Chugh, D. (2012). Temporal distance and discrimination: An audit study in academia. Psychological Science, 23, 710-717.

62. Sah, S., \& Loewenstein, G. (2012). More affected = more neglected: Amplification of bias in advice to the unidentified and many. Social Psychological and Personality Science, 3, 365-372.

63. Jensen, R. (2005). The heart of Whiteness: Confronting race, racism and White privilege. San Francisco, CA: City Lights Books

64. Lowery, B. S., Knowles, E. D., \& Unzueta, M. M. (2007). Framing inequity safely: Whites' motivated perceptions of racial privilege. Personality and Social Psychology Bulletin, 33 , 1237-1250

65. Mclntosh, P. (1998). White privilege: Unpacking the invisible knapsack. In P. S. Rothenberg (Ed.), Race, class, and gender in the United States: An integrated study (4th ed., pp. 165-169). New York, NY: Worth.

66. United States Department of Justice, Civil Rights Division. (2015). Investigation of the Ferguson Police Department. Retrieved from http://www.justice.gov/sites/default/files/opa/ press-releases/attachments/2015/03/04/ferguson_police_ department_report.pdf

67. Loewenstein, G., Sah, S., \& Cain, D. M. (2012). The unintended consequences of conflict of interest disclosure. Journal of the American Medical Association, 307, 669-670. doi:10.1001/ jama.2012.154

68. Sah, S., \& Loewenstein, G. (2015). Conflicted advice and second opinions: Benefits, but unintended consequences. Organizational Behavior and Human Decision Processes, 130, 89-107.

69. Sah, S., Loewenstein, G., \& Cain, D. M. (2013). The burden of disclosure: Increased compliance with distrusted advice. Journal of Personality and Social Psychology, 104, 289-304.

70. Bertrand, M., \& Mullainathan, S. (2004). Are Emily and Greg more employable than Lakisha and Jamal? A field experiment on labor market discrimination. The American Economic Review, 94, 991-1013.

71. Kutateladze, B. L., \& Andiloro, N. R. (2014). Prosecution and racial justice in New York County-Technical report (Technical Report 247227). Retrieved from National Criminal Justice Reference Service website: https://www.ncjrs.gov/pdffiles1/nij/ grants/247227.pdf

72. Gershowitz, A. M., \& Killinger, L. (2011). The state (never) rests: How excessive prosecutor caseloads harm criminal defendants. Northwestern University Law Review, 105, 262-301.

73. Perry, S., \& Banks, D. (2011). Prosecutors in state courts-2007 statistical tables (NCJ 234211). Retrieved from Bureau of Justice Statistics website: http://www.bjs.gov/content/pub/pdf/ psc07st.pdf

74. U.S. Department of Justice. (2011). United States attorneys' annual statistical report: Fiscal year 2010. Retrieved from http://www.justice.gov/sites/default/files/usao/ legacy/2011/09/01/10statrpt.pdf

75. Rosenmerkel, S., Durose, M., \& Farole, D., Jr. (2009). Felony sentences in state courts, 2006-Statistical tables (NCJ 226846). Retrieved from Bureau of Justice Statistics website: http://www.bjs.gov/content/pub/pdf/fssc06st.pdf

76. Schmitt, J., Warner, K., \& Gupta, S. (2010). The high budgetary cost of incarceration. Retrieved from Center for Economic and Policy Research website: http://www.cepr.net/publications/ reports/the-high-budgetary-cost-of-incarceration

77. Western, B., \& Pettit, B. (2010). Collateral costs: Incarceration's effect on economic mobility. Retrieved from Pew Charitable Trusts website: http://www.pewtrusts.org/ /media/legacy/ uploadedfiles/pcs_assets/2010/collateralcosts1pdf.pdf

78. Tyler, T. R. (1990). Why people obey the law: Procedural justice, legitimacy, and compliance. New Haven, CT: Yale University Press. 